\title{
溶融アルミニウムと無電解銅めっきした $\mathrm{Al}_{2} \mathrm{O}_{3}$ の濡れ
}

\author{
宮原広 郁 ${ }^{\dagger}$ 森 信幸 大城桂 作
}

九州大学工学部材料工学科

J. Japan Inst. Metals, Vol. 57, No. 7 (1993), pp. 797-803

\section{Wettability between Molten Aluminum and Electroless Copper Plated $\mathrm{Al}_{2} \mathrm{O}_{3}$}

Hirofumi Miyahara, Nobuyuki Mori and Keisaku Ōgi

Department of Materials Science and Engineering, Faculty of Engineering, Kyushu University, Fukuoka

The effect of electroless copper plating 0.08 to $4.5 \mu \mathrm{m}$ thick on the wettability of $\mathrm{Al}_{2} \mathrm{O}_{3}$ substrate and fiber preform by molten aluminum were investigated with the sessile drop method in a vacuum of $2 \times 10^{-3} \mathrm{~Pa}$ at temperatures from 973 to $1173 \mathrm{~K}$.

The contact angle of molten aluminum on $\mathrm{Al}_{2} \mathrm{O}_{3}$ substrate decreased from $113^{\circ}$ to $92^{\circ}$ as the temperature rose from 973 to $1173 \mathrm{~K}$. The electroless copper plating on $\mathrm{Al}_{2} \mathrm{O}_{3}$ reduced the contact angle to less than $40^{\circ}$ when the thickness of plating was larger than $0.3 \mu \mathrm{m}$ at $973 \mathrm{~K}$. The apparent contact angles between molten aluminum and 15 volume $\% \mathrm{Al}_{2} \mathrm{O}_{3}$ fiber preform were about $140^{\circ} \sim 145^{\circ}$ at $973 \sim 1073 \mathrm{~K}$. Electroless copper plating reduced the angle, and molten aluminum was spontaneously infiltrated into preform when the thickness of plating was larger than $0.5 \mu \mathrm{m}$ at $973 \mathrm{~K}, 1.4 \mu \mathrm{m}$ at $1073 \mathrm{~K}$. The thin copper plating could not improve the wettability, because copper deposits on $\mathrm{Al}_{2} \mathrm{O}_{3}$ coagulated due to the surface energy and the $\mathrm{Al}_{2} \mathrm{O}_{3}$ surface was partially exposed at high temperatures. The coagulation became more remarkable as temperature rose. By these phenomena, the molten Al drop, which once spread on the copper plated $\mathrm{Al}_{2} \mathrm{O}_{3}$ substrate, moved back towards the receding contact angle. The interaction between the coated copper and the molten aluminum was metallographically investigated.

(Received January 6, 1993)

Keywords: wettability, contact angle, molten aluminum alloy, alumina, electroless plating, preform, infiltration, composites

I 。緒言

ボルテックス法(1)(2)，コンポキャスト法スクイズキャスト 法(3)など液体金属を用いて金属とせラミックスの複合材料を製 造する方法では，溶融金属とセラミックスの濡れ性が良いこと が望まれる. $\mathrm{Al}_{2} \mathrm{O}_{3}$ に対する溶融 $\mathrm{Al}$ の濡れ性红温度の上昇と ともに向上するが，実際の Al 合金鋳造法での溶解温度 1023 $1123 \mathrm{~K}$ 近傍では平滑な $\mathrm{Al}_{2} \mathrm{O}_{3}$ 基盤に対する接触角は $90^{\circ}$ ～ $110^{\circ}$ の値であり(4)(ら，表面が粗くなるとさらに需机性が低下 し，複合化には十分な条件とは言えない。そこで，濡れ性を大 幅に改善する方法として，金属膜で $\mathrm{Al}_{2} \mathrm{O}_{3}$ 表面を被覆する方 法が考光られ(6)(7)，著者らは $\mathrm{Al}_{2} \mathrm{O}_{3}$ 基盤に $\mathrm{Ni}$ をイオンプレー ティング法で被覆した場合，1073 K 保持では皮膜の厚さが $0.5 \mu \mathrm{m}$ 以上で接触角が $5^{\circ}$ 以下となり，需れ性が著しく向上す ることを示した(7)、しかし，イオンプレーティング法ではセラ ミックス瀻維や粒子の表面処理は困難なるのとなる. 本研究で は, より安価で大量生産に適している無電解めっき法(8)-(11) K 上り， $\mathrm{Al}$ 溶湯との濡れ性が良く，構造用 $\mathrm{Al}$ 合金の成分元素と

†州大学大学院生
して利用されている $\mathrm{Cu}$ を $\mathrm{Al}_{2} \mathrm{O}_{3}$ 表面に種々の膜厚で被覆し, 溶融 $\mathrm{A} 1$ との濡孔性と界面反応を調査した。

\section{II、実験 方 法}

\section{1. 実験試料}

液滴用金属には，高純度 $\mathrm{Al}$ (99.99 mass\%) 拉よび $\mathrm{Cu}(99.9$ mass\%)を原料として溶製した純 Al，A1-5.5 mass\%Cu 抌よび $\mathrm{Al}-33.0$ mass\% Cu $0.5 \sim 1 \mathrm{~g}$ の立方体試片として，アセトン で超音活洗浄を施して用いた，固体基盤には，市股の透光性 $\mathrm{Al}_{2} \mathrm{O}_{3}$ 基艋(東芝セラミックス㑣)，TPA-10，純度 $\mathrm{Al}_{2} \mathrm{O}_{3}>99.9$ $\operatorname{mass} \%, \alpha-\mathrm{Al}_{2} \mathrm{O}_{3}$, 多結晶) $28 \mathrm{~mm} \times 28 \mathrm{~mm} \times 3 \mathrm{~mm}$ の板状試 片とし，表面を鏡面仕上げ(表面粗さ $R_{\mathrm{a}}=0.05 \mu \mathrm{m}$ ) した鏡面基 盤と機械仕上げ $\left(R_{\mathrm{a}}=4.0 \mu \mathrm{m}\right)$ した粗面基盤の 2 種類使用した。 基盤表面の清浄度执よび高温での安定性の向上を目的として， いずれの基盤ともあらかじめアセトンで超音波洗浄後，1173 K, $2 \times 10^{-3} \mathrm{~Pa}$ で $3600 \mathrm{~s}$ 空焼きし実験に供した. Fig. 1(a)， (b)に各基盤の表面のSEM 像を示したが，鏡面仕上げ面には 面積率で約 $8 \%$ のボイドが認められる。また, 溶融 $\mathrm{A} 1$ との濡 れ珄を改善するために, この 2 種類の $\mathrm{Al}_{2} \mathrm{O}_{3}$ 基盤上に無電解

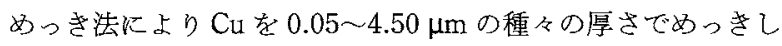



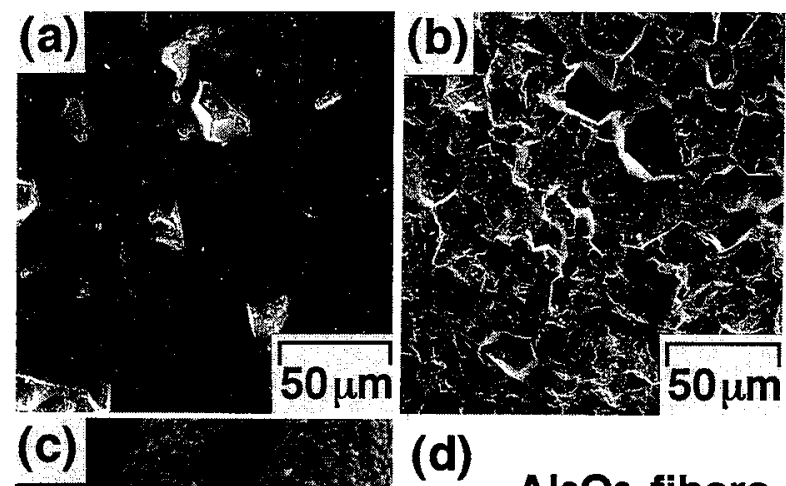

(d)
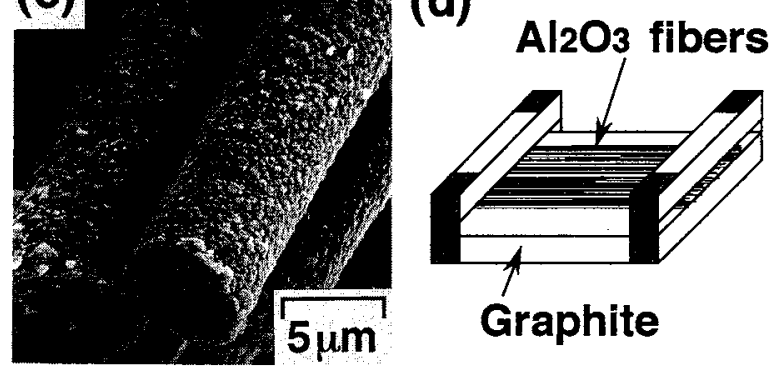

Fig. 1 Scanning electron micrographs of the specimen (a) smooth surface, (b) rough surface and (c) $\mathrm{Al}_{2} \mathrm{O}_{3}$ fibers. (d) Schematic view of the fiber preform.

た. 無電解めっきは上村工業株式会社の「スルカップ・プロせ ス」に準じて行った，各試片の端の一部を粘着テープで覆い, めっき処理後にテープを取り，無めっき部とめっき部の高さの 差を超精密表面粗さ計 (タリステップ)で測定して皮膜の厚さと した.めっさした基盤は常温で十分に乾燥し, 濡れ実験に供し た、な拉，従来の研究(7) と比較する目的から鏡面基盤を使用 し，また $\mathrm{Al}_{2} \mathrm{O}_{3}$ 基盤と $\mathrm{Cu}$ 膜との付着力は主として $\mathrm{Al}_{2} \mathrm{O}_{3}$ 基盤 上に存在する気孔との投錯(アンカー) 效果に依るるのとされて いる(8)-(11)ため，付着力を高める目的から粗面基盤も準備し た.さらに，純 Cu 板を $28 \mathrm{~mm} \times 28 \mathrm{~mm} \times 3 \mathrm{~mm}$ の試片に加工 し，表面を鏡面仕上げして溶融 $\mathrm{Al}$ との濡れ挙動を調查し，コ ーティング基盤の場合と比較した.

次に, $\mathrm{Al}_{2} \mathrm{O}_{3}$ 長瀻維に対する溶融 $\mathrm{A} 1$ の濡れ性を調査するた め, $\mathrm{Al}_{2} \mathrm{O}_{3}$ 繊維 (三井鉱山(侏)，アルマックス, $\mathrm{Al}_{2} \mathrm{O}_{3}>99.9$ mass\%, 直径 $10 \mu \mathrm{m}, \alpha-\mathrm{Al}_{2} \mathrm{O}_{3}$, 多結晶, Fig. $1(\mathrm{c})$ ) t長さ 30 $\mathrm{mm}$ 火切断し，基盤の場合と同様にアセトンで超音波洗浄と空 焼さをした後, Fig. 1(d)のように各瀻維が平行かつ平坦にな るように整列させ，幅 $20 \mathrm{~mm}$, 厚さ $3 \mathrm{~mm}$ の板状のプリフォ ームとして実験に供した。 また，無電解めっき法により $\mathrm{Cu}$ $0.2 \sim 1.4 \mu \mathrm{m}$ コーティングしたプリフォームも作製し, 溶融

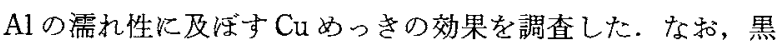

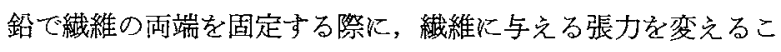
とにより䊼維体積率を変化させることがでさ，体積率 $\left(V_{\mathrm{f}}\right)$ $15 \%$ と $9 \%$ の試料を作製した. 織維の平均体積率は，樹脂に埋 めた試料を瀻維の長さ方向と垂直に切断し検鏡したところ, 緎 維は一様に分布していたので, 単位面積女たりの瀻維の数を測 定し面積率として求めた.

\section{2. 実験装置および方法}

濡れ性測定実験は，液滴滴下装置を用いた静滴法により行っ $た^{(12)}$. 真空炉内に空焼きした $\mathrm{Al}_{2} \mathrm{O}_{3}$ 基盤をセットし， $2 \sim 5 \times$ $10^{-3} \mathrm{~Pa}$ 程度玉で真空排気した後に昇温を開始し，所定の真空 度 (約 $\left.2 \times 10^{-3} \mathrm{~Pa}\right)$ と, 测定温度 $(973,1073$ 抌よび $1173 \mathrm{~K})$ に 達した後, 液滴滴下装置により液滴を基盤または繊維プりフォ 一ム上に静か㯰いた：基盤の底面に接触させた PR 熱電対に より浿温を行い，測定温度を保持しながら所定時刻毎に写真撮 影を行った。接触角の測定は，デジタイザーを用いて写真の液 滴形状扣よび基盤表面をトレースし，基盤面での曲線の勾配か ら接触角救めた。 李た液滴滴下後, 所定の温度で $3600 \mathrm{~s}$ 保 持した後，割型炉を開いて約 $2 \mathrm{~K} / \mathrm{s}$ の伶却速度で凝固させた 試料を作成し, $\mathrm{Al}_{2} \mathrm{O}_{3}$ 表面执よび液滴と $\mathrm{Al}_{2} \mathrm{O}_{3}$ との界面を SEMにより観察するとともに，EPMAにより反应層の組成を 分析した。

\section{III. 実験結果および考察}

\section{1. $\mathrm{Al}_{2} \mathrm{O}_{3}$ 基盤と溶融 $\mathrm{Al}$ 合金の濡れ性}

Fig. 2 に $\mathrm{Al}_{2} \mathrm{O}_{3}$ 基盤飞対する純 $\mathrm{Al}, \mathrm{Al}-5.5$ mass $\% \mathrm{Cu}$ および Al-33 mass\% $\mathrm{Cu}$ 合金の接触角 $(\theta)$ と温度 $(T)$ の関係を示した.

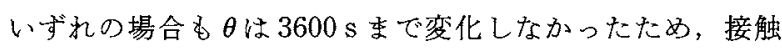
時間が $300 \mathrm{~s} の$ 值を代表值とした。純 $\mathrm{Al} の \theta$ は $973 \mathrm{~K}$ 保 持で $113^{\circ}$ であり，温度の上昇とともに低下し，1173 K 保 持では $\theta=92^{\circ}$ を示した。この $\theta$ は Brennanと Pask $^{(4)}$ や Prabriputaloong と Piggott ${ }^{(5)}$ の文献值とほぼ同様の值である. Al-5.5 扣よび 33 mass\% $\mathrm{Cu}$ 合金の $\theta$ る純 $\mathrm{Al}$ と汪ぼ同じ值で 市った。

\section{2. 無電解銅めっきした $\mathrm{Al}_{2} \mathrm{O}_{3}$ 基盤と溶融 $\mathrm{Al}$ の濡れ性}

Fig. 3 K，種々の膜厚で $\mathrm{Cu}$ めっを施した $\mathrm{Al}_{2} \mathrm{O}_{3}$ 基盤に対 する溶融 $\mathrm{Al}$ の接触角 $(\theta)$ の時間变化を, $973 \mathrm{~K}$ 保持で測定し た結果を示した，李た図中には無めっきの純 $\mathrm{Al}_{2} \mathrm{O}_{3}$ 基盤およ び純 Cu 基盤との接触角車記入した．鏡面基盤(“smooth”之表 示)に执いて，無めっきの基盤は $\theta=113^{\circ}$ で $3600 \mathrm{~s}$ 保持しても 変化はなかった。これに対して，皮膜の厚さ $(\delta)$ が比較的薄い

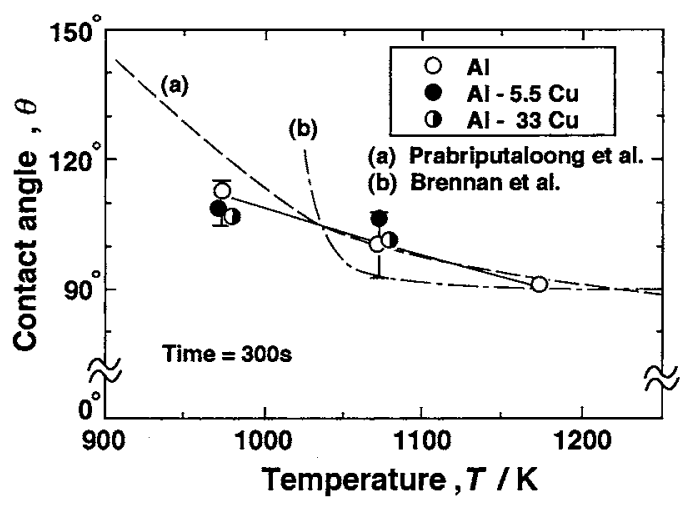

Fig. 2 Contact angle vs. temperature for molten $\mathrm{Al}$ and Al-Cu alloys on $\mathrm{Al}_{2} \mathrm{O}_{3}$ substrate. 


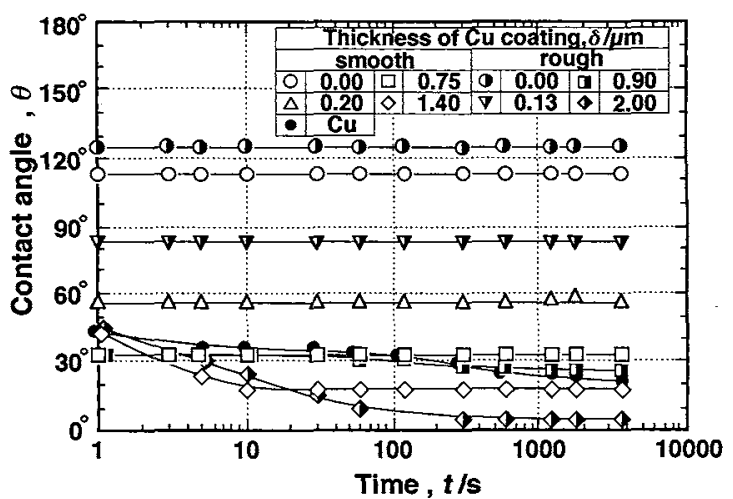

Fig. 3 Contact angle vs. time for molten $\mathrm{Al}$ on Cu-plated $\mathrm{Al}_{2} \mathrm{O}_{3}$ at $973 \mathrm{~K}$.

試料では $\theta$ の時間変化はないが， $\delta=0.2 \mu \mathrm{m} て ゙ ~ \theta=56^{\circ}$, $\delta=0.75 \mu \mathrm{m}$ では $\theta=33^{\circ}$ と $\delta$ の増加に伴い $\theta$ の值は低下した. 一方， $\delta$ が $1.4 \mu \mathrm{m}$ 以上と厚い場合や純 $\mathrm{Cu}$ 基盤では，液滴滴 下直後から $\theta$ 約 $40^{\circ}$ と低い值を示し，10 300 s でさらに低 下し，その後 $3600 \mathrm{~s}$ をで低い $\theta$ を維持した。機械仕上げのま 末の粗面基盤 (“rough”之表示)の場合も以上の鏡面基盤と汇 济同様の時間依存性を示し，めっきしていない基盤では

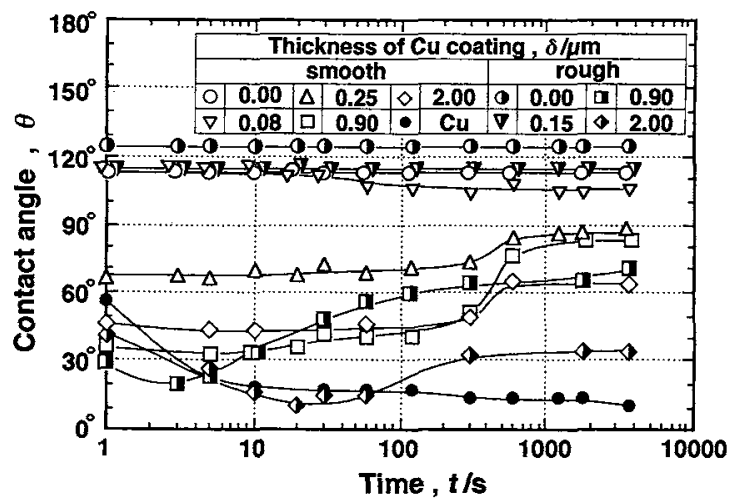

Fig. 4 Contact angle vs. time for molten $\mathrm{Al}$ on $\mathrm{Cu}$-plated $\mathrm{Al}_{2} \mathrm{O}_{3}$ at $1073 \mathrm{~K}$.

$\theta=126^{\circ}$ で $3600 \mathrm{~s}$ まで一定であるのに対し， $\delta か ゙ ~ 0.9 \mu \mathrm{m}$ と厚

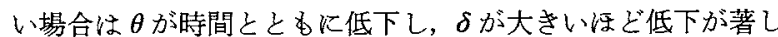
い。なお，無めっき基盤の $\theta$ が鏡面基盤の $\theta$ よりも高い値を 示すのは，表面粗さが $R_{\mathrm{a}}=4.0 \mu \mathrm{m}$ と大きく，基艋表面の凹部 には液滴が入り込まず，基盤表面と液滴が接する界面の面積が 見かけの值より小さくなるためで岁る(13)(14)。このときの $\theta$ は 表面性状を考虑したCassie の式(15) 従らと考克られる。すな
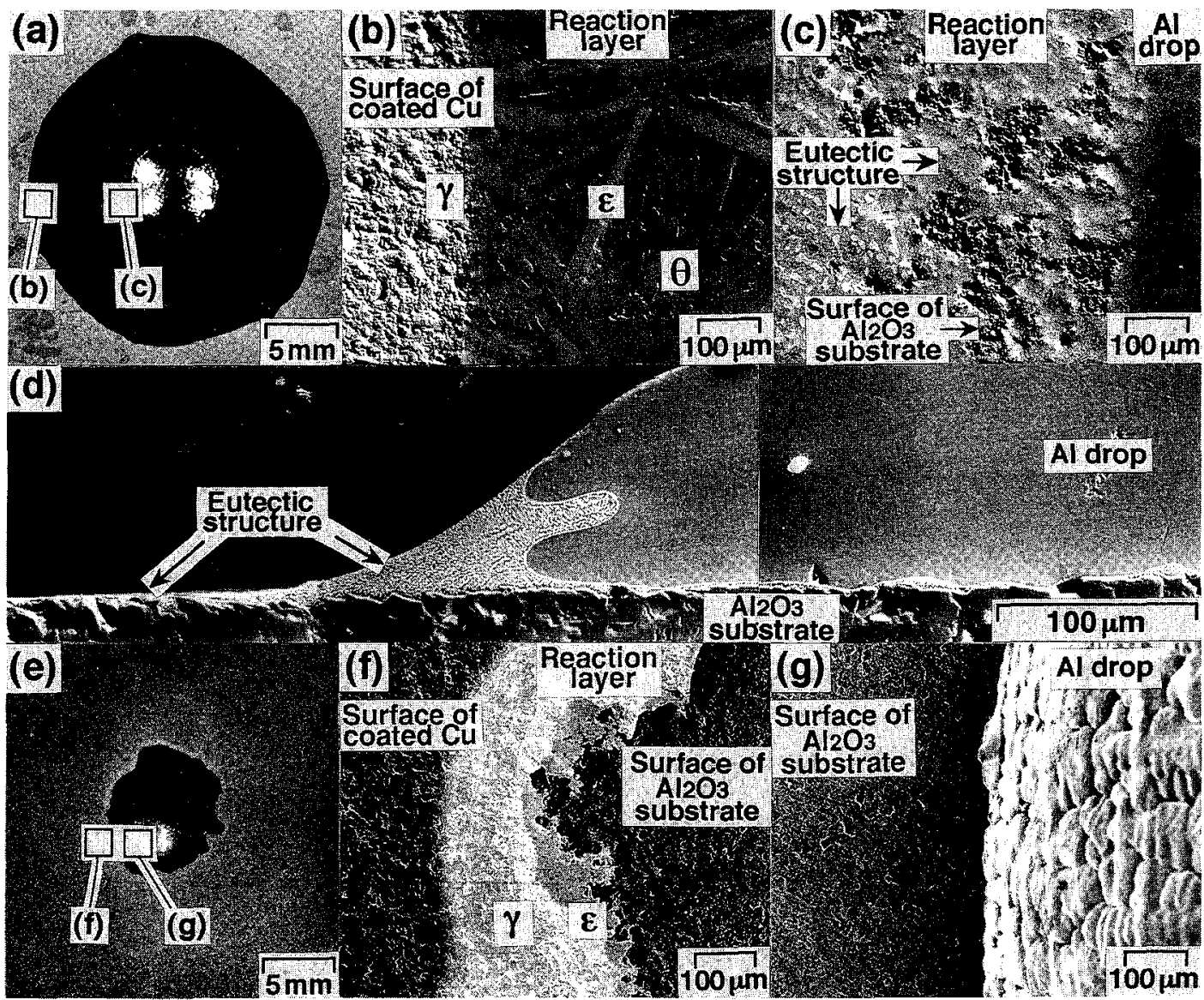

Al drop
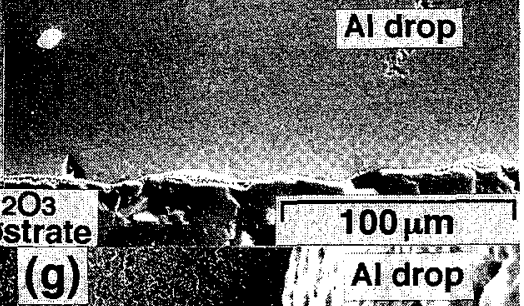
Surface of substrate $\mathrm{Al}_{203}$ substrate

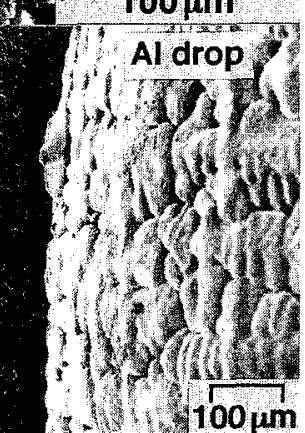

Fig. 5 Optical micrographs and scanning electron micrographs of $0.9 \mu \mathrm{m}$ thick $\mathrm{Cu}$-plated $\mathrm{Al}_{2} \mathrm{O}_{3}$ surface (wetting time: $3600 \mathrm{~s}),(\mathrm{a}) \sim(\mathrm{c})$ and $(\mathrm{d})$ held at $973 \mathrm{~K},(\mathrm{e}) \sim(\mathrm{g})$ held at $1073 \mathrm{~K}$. 
わち，

$$
\cos \theta=\mathrm{f}_{1} \cos \theta_{1}+\mathrm{f}_{2} \cos \theta_{2}
$$

ただし， $\mathrm{f}_{1}, \mathrm{f}_{2}$ はとれぞれ相 1 , 相 2 と融液の界面面積率であ り， $\theta_{1}, \theta_{2}$ は相 1 ，相 2 亿対する融液の接触角である.ここで は相 2 は気孔であるため $\theta_{2}=180^{\circ}$ となる. Fig. 2 より $\theta_{1}$ $=113^{\circ}$ を代入し, 基盤の面積の $35 \%$ が凹凸のため液滴と接触 していないと仮定すると $\theta=126^{\circ}$ を得る.

Fig. 4 は $1073 \mathrm{~K}$ 保持の場合の $\theta$ の時間変化を示したもので あるが，鏡面执よび粗面基盤のいずれの場合も，皮膜の厚さが $\delta \leqq 0.15 \mu \mathrm{m}$ の比較的薄い場合には $\theta$ の低下は少なく, 時間変 化もほとんどみられない。しかし， $\delta=0.25 \sim 2.0 \mu \mathrm{m}$ の場合は 液滴滴下直後から $1 \sim 20 \mathrm{~s}$ で $\theta$ が低下し，その後再び上昇して $300 \sim 600 \mathrm{~s}$ で変化が少なくなり，3600 s 保持までほぼ一定の 值を維持した.

そこでこの原因を調査するため，代表的な試料として $\delta=0.9 \mu \mathrm{m}$ の粗面基盤の場合について， $\theta$ が $25^{\circ}$ を示した 973 $\mathrm{K}$ 保持の試料と再び $\theta$ が上昇して $\theta=70^{\circ}$ を示した $1073 \mathrm{~K}$ 保 持の試料を $2 \mathrm{~K} / \mathrm{s}$ で冷却して凝固させ，液滴端部の組織を観 察した。その結果をFig. 5 に示す． $973 \mathrm{~K}$ 保持の場合，Fig. 5 (a) に示されるように, 約 $\phi 5 \mathrm{~mm}$ の $\mathrm{Al}$ 液滴の周囲には約 $\phi 20 \mathrm{~mm}$ の $\mathrm{Cu}$ 皮膜と液滴の反応層が観察された. EPMA を用 いて反応層を分析したところ，Fig. 5(c) に示すよらに液滴の 周囲は共晶組織が多く占め, わずかに $\mathrm{Al}_{2} \mathrm{O}_{3}$ が露出して括り, その外側には共晶組織中に棈円または不定形の $\theta$ 相が存在し た。さらにその外側には $\theta$ 単相, 棒状の $\varepsilon$ 相 (Fig. 5(b)), 抒 よびめっき層に沿った $\gamma$ 相 (Fig. 5(b))が観察された. 試料を 基盤表面と垂直に切断してその断面を観察したところ, 液滴中 心部の $\mathrm{Cu}$ の平均組成は 2.1 mass\%と低かったが，Fig. 5(d) に示すように基盤と接して液滴最外郭部には約 $100 \mu \mathrm{m}$ の幅で 共晶が大部分を占める組織が認められた。これらのことから， 高温保持中は，液滴は約 $33 \mathrm{mass} \%$ の $\mathrm{Cu}$ 濃度を持つ液滴最外 郭部が，やはり $\mathrm{Cu}$ 濃度が約 33 mass\%の融液と $\mathrm{Al}_{2} \mathrm{O}_{3}$ から成 る混合表面 (Fig. 5(c)) と接触した状態になっていたと思われ る. また，基盤表面の融液の膜は液滴から離れるにつれて徐々 飞 $\mathrm{Cu}$ 濃度が上昇して括り (Fig. 5(b)，(c)), Al-Cu 系状態図 ${ }^{(16)}$ から予測されるよらに未反応めっき部近傍では $\varepsilon$ 抽よび $\gamma$ 相が 生成していたと考兄られる.これに対して，Fig. 5(e)〜 (g)の $1073 \mathrm{~K}$ 保持の場合は，反応層と溶融 $\mathrm{Al}$ 間に $\mathrm{Al}_{2} \mathrm{O}_{3}$ 基盤表面 が露出して扣り，一度濡れて広がった液滴が後退した跡を示し ている. 皮膜近傍では，Fig. 5(f) と示すように灰色の $\varepsilon$ 拉よび 白色の $\gamma$ 相が認められた。液滴の断面を観察したところ, 液 滴中の $\mathrm{Cu}$ はほぼ一椂に分布し, 平均濃度は約 1.8 mass\%であ った。このことから，1073 K 保持の場合は液滴が後退した後 は $\mathrm{Al}-1.8$ mass\% $\% \mathrm{Cu}$ の液滴と $\mathrm{Al}_{2} \mathrm{O}_{3}$ 基盤との濡れであったと 考光られる。

次に各温度に扣ける接触角 $(\theta)$ と $\mathrm{Cu}$ 膜の厚さ $(\delta)$ の関係を Fig. 6 に示した. このとき各基盤の $\theta$ の代表值としては，従 来から測定値の多い $300 \mathrm{~s}$ と時間変化の少ない $3600 \mathrm{~s}$ 保持し た時の值を採用した．図中の実線は鏡面基盤(“smooth”と表 示)に対する $300 \mathrm{~s}$ 接触後の值を各保持温度ごとに結んだ線で ある. 鏡面基盤の $\theta$ は，いずれの温度の場合も $\delta$ が増加する と減少する傾向がある．特に $973 \mathrm{~K}$ 保持の場合， $\delta$ を約 0.3

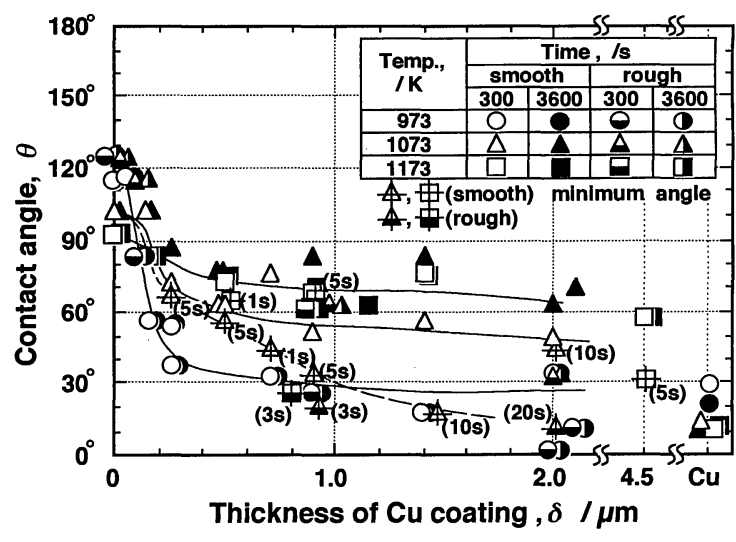

Fig. 6 Contact angle vs. thickness of $\mathrm{Cu}$ coating for molten $\mathrm{Al}$ on $\mathrm{Cu}$-plated $\mathrm{Al}_{2} \mathrm{O}_{3}$ at 973,1073 and $1173 \mathrm{~K}$ (wetting time: $300 \mathrm{~s}$ and $3600 \mathrm{~s}$ ).

$\mu \mathrm{m}$ まで増加させると $\theta$ は著しく低下し， $\delta=0.3 \mu \mathrm{m}$ では $40^{\circ}$ 以下となり濡れ性改善に及ぼす $\mathrm{Cu}$ コーティングの効果が影著 であった．一方，より高温である $1073 \mathrm{~K}, 1173 \mathrm{~K}$ 保持の場合 には, $\delta$ が約 $0.2 \mu \mathrm{m}$ までは $\delta$ の増加とともに $\theta$ は減少するが， $\delta=0.3 \mu \mathrm{m}$ 以上で $\theta=60 \sim 80^{\circ}$ の比較的大きい值で停滞する傾 向がみられる。これは，一度濡れた液滴が戻る現象の起こる膜 厚に対応して扣り，最も良く濡れたときの接触角を十字付きデ 一タ (A 印など) と破線で示すとともに最小の $\theta$ を示した時間 をカッコ内 $((5 \mathrm{~s})$ など)に示した。

無電解めっきした粗面基盤に対する溶融 $\mathrm{Al}$ の $\theta$ (“rough”と 表示) も，同図中に記入した.コーティングしていない粗面基 盤の $\theta$ は表面の凹凸の影響のため鏡面基盤に対する接触角よ りも高くなっている(15)が，Cuをコーティングした基盤では $\delta=0.9 \mu \mathrm{m}$ の場合の，保持温度 1073 和よび $1173 \mathrm{~K}$ に打ける最 小接触角の值や， $\delta=2.0 \mu \mathrm{m}, 973 \mathrm{~K}$ に括ける接触角の值に示 されるように，鏡面基盤の場合と比較して濡れ性の改善効果は 高い，これは，後述するように基盤に対する $\mathrm{Cu}$ 膜の付着力が 鏡面基盤の場合よりも高いこと，また，Wenzelによると $\theta<90^{\circ}$ の粗面では，見かけの表面積より真の面積が大きくな るため，濡れ性が良くなったと考兄られる(13).

$\mathrm{Cu}$ を被覆することにより溶融 $\mathrm{Al}$ との濡れ性を改善するた めには，一様な皮膜を形成することが重要となる．Fig. 7 に 濡れ実験の $973 \mathrm{~K}$ 抢よび $1073 \mathrm{~K}$ 亿昇温(濡れ実験温度まで約 $0.3 \mathrm{~K} / \mathrm{s}$ で昇温した)招よび恒温保持したときの皮膜の性状の 変化を示した. Fig. 7(a) 拉よび(e)のめっきしたままでは基盤 の平滑面だけでなく窪みにも一様に Cu が被覆されているが，

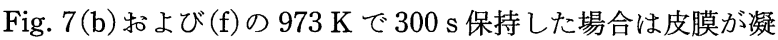
集して $\mathrm{Al}_{2} \mathrm{O}_{3}$ 表面が露出している. 本実験では所定の温度に 到達してから装置内の温度を安定させるため約 $300 \mathrm{~s}$ 保持して 濡れ実験を開始しており，この Fig. 7(b) および(f)は液滴滴下 時での皮膜の状態を示している.さらに Fig. 7(c) 拉よび $(\mathrm{g})$ に 見られるように同一の膜厚では保持温度が高い注ぞ原子の拡散 性が増すため，凝集し易いと考号られる．表面粗さも $\mathrm{Cu}$ 皮膜 の凝集に影響を与光，Fig. 7(b) 特よび(c)の鏡面に対して Fig. 7(f) 执よび (g) の粗面の場合には $\mathrm{Cu}$ 皮膜は凸部で優先的 に凝集し，凹部では凝集の程度が少ない，凝集によって生じる 


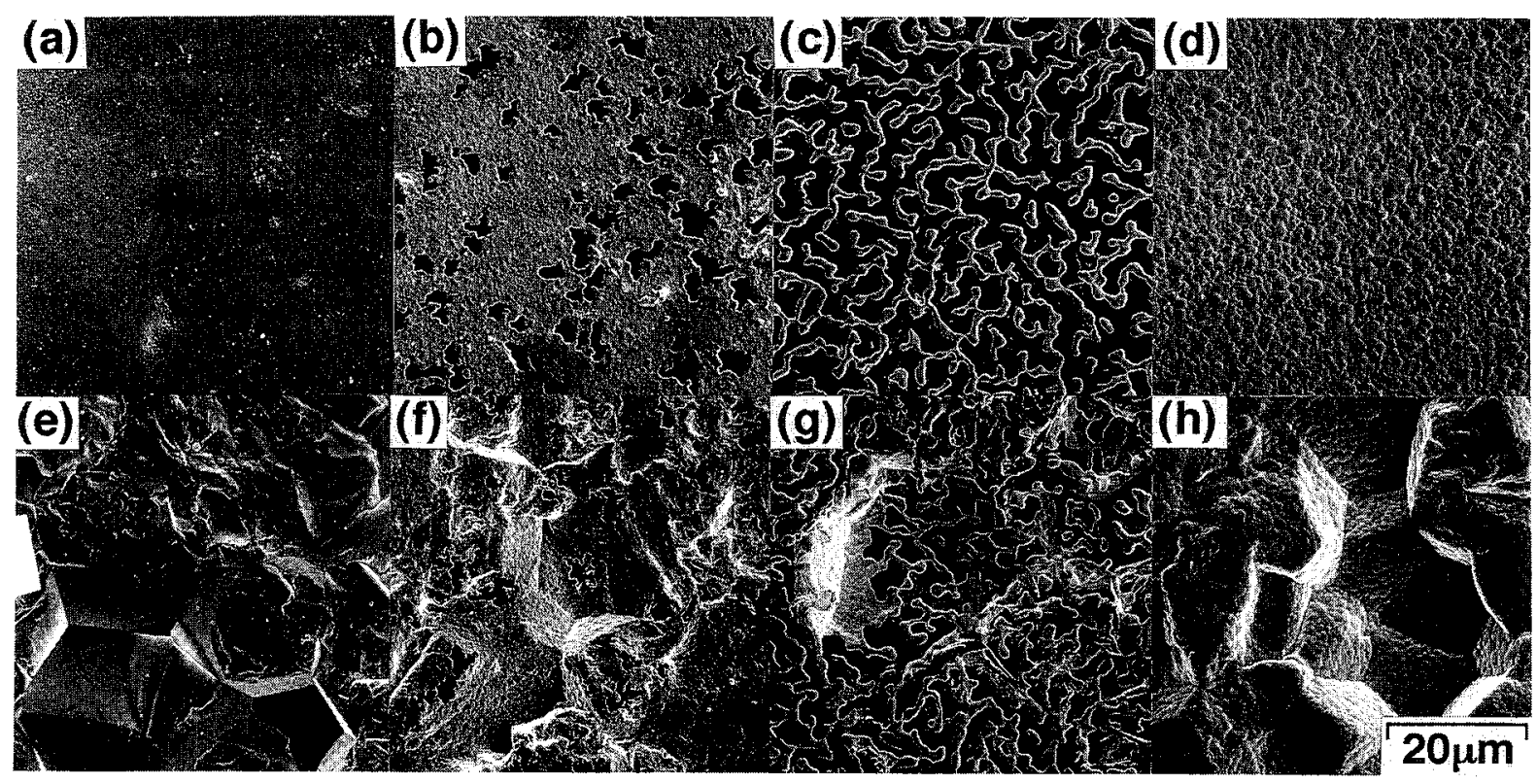

Fig. 7 Influence of thickness of $\mathrm{Cu}$ coating, surface roughness, holding temperature and time on the surface structure of Cu-plated $\mathrm{Al}_{2} \mathrm{O}_{3}$. (a) $\mathrm{Al}_{2} \mathrm{O}_{3}+0.3 \mu \mathrm{m} \mathrm{Cu}$, smooth surface, as electroless plated, (b) $\mathrm{Al}_{2} \mathrm{O}_{3}+0.3 \mu \mathrm{m} \mathrm{Cu}$, smooth surface, 973 $\mathrm{K}-300 \mathrm{~s}$, (c) $\mathrm{Al}_{2} \mathrm{O}_{3}+0.3 \mu \mathrm{m} \mathrm{Cu}$, smooth surface, $1073 \mathrm{~K}-300 \mathrm{~s}$, (d) $\mathrm{Al}_{2} \mathrm{O}_{3}+0.9 \mu \mathrm{m} \mathrm{Cu}$, smooth surface, $1073 \mathrm{~K}-300 \mathrm{~s}$, (e) $\mathrm{Al}_{2} \mathrm{O}_{3}+0.3 \mu \mathrm{m} \mathrm{Cu}$, rough surface, as electroless plated, (f) $\mathrm{Al}_{2} \mathrm{O}_{3}+0.3 \mu \mathrm{m} \mathrm{Cu}$, rough surface, $973 \mathrm{~K}-300 \mathrm{~s}$, (g) $\mathrm{Al}_{2} \mathrm{O}_{3}$ $+0.3 \mu \mathrm{m} \mathrm{Cu}$, rough surface, $1073 \mathrm{~K}-300 \mathrm{~s}$, (h) $\mathrm{Al}_{2} \mathrm{O}_{3}+0.9 \mu \mathrm{m} \mathrm{Cu}$, rough surface, $1073 \mathrm{~K}-300 \mathrm{~s}$.

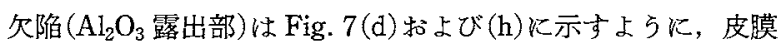
の厚さを厚くすることによりその生成を抑奌ることができ， $1073 \mathrm{~K}$ 保持でる $0.9 \mu \mathrm{m}$ 以上では忹とんど見られない，

Fig. 6机いて皮膜が凝集する $\delta$ の範囲(973 K 保持で $\delta<0.5 \mu \mathrm{m}, 1073 \mathrm{~K}$ 保持で $\delta<0.9 \mu \mathrm{m})$ では，基盤表面は凝集 した $\mathrm{Cu}$ と露出した $\mathrm{Al}_{2} \mathrm{O}_{3}$ が混在している状態であるため， $\mathrm{Al}$ 液滴はこの複合表面に対する濡れとなり，濡れ性に及洼す 皮膜の効果性くなると考方られる。一方，皮膜にほとんど欠 陷が生じない $\delta$ が厚い場合 $(973 \mathrm{~K}$ では $\delta \geqq 0.5 \mu \mathrm{m}, 1073 \mathrm{~K}$ で は $\delta \geqq 0.9 \mu \mathrm{m})$ には Al 液滴が連続的に $\mathrm{Cu}$ 層を溶解しながら広 がって濡れが進行し，接触角は低下していく．しかし，この場 合に和いても $\mathrm{Al}_{2} \mathrm{O}_{3}$ 基盤と皮膜の間に間腺などの欠陷方存在 する場合には溶融 $\mathrm{Al}$ は局部的に $\mathrm{Al}_{2} \mathrm{O}_{3}$ との濡れになるため, この久陷を起点にして Al 液滴自身の表面張力で後退し始め, 後退接触角を示寸位置まで $\theta$ が上昇するものと思われる。こ のような皮膜と $\mathrm{Al}_{2} \mathrm{O}_{3}$ 基盤間の欠陷が生じる原因としては， 無電解銅めっき法が化学反応を用いた膜生成法で西り，Cu膜 の $\mathrm{Al}_{2} \mathrm{O}_{3}$ 基盤への付着力は, 主として基盤表面存在する孔 への投錯効果によるとされて和り(8)-(11)，ミク口的に平滑な部 分では皮膜と $\mathrm{Al}_{2} \mathrm{O}_{3}$ 基盤との間以間隙が生じる可能性が考点 られる.実際に鏡面仕上げ基盤では局所的に $\mathrm{Cu}$ めっ層が剥 離する現象も認められた。さらに，めっさされた $\mathrm{Cu} は \mathrm{Al}_{2} \mathrm{O}_{3}$ との需れが悪く, 高温では凝集しやすいことが久陷の生成を助 長すると考えられる。これ対し，粗面基盤では表面での凹凸 により投錨效果に寄与する面積が広く，かつ付着力が大きいた め上記の現象が生じにくく，溶融 $\mathrm{Al}$ との濡れ性が鏡面基盤之 の場合より必優れたと考兄られる。

なお，著者らはイオンプレーティングルより $\mathrm{Ni}$ を被覆した 基盤に対しても溶融 $\mathrm{Al}$ との濡れ性を本実験と同じ装置を用い
て調查した(7). 鏡面基盤に括いて Ni 皮膜の厚さの増加ととも に接触角は低下し, $973 \mathrm{~K}$ 保持では膜の厚さが $0.2 \mu \mathrm{m}$ 以上で $\theta$ は $5^{\circ}$ 以下を示し, 本実験の $\theta=20^{\circ} \sim 40^{\circ}$ の値よりる低かっ た.上り高温である $1073 \mathrm{~K}$ 保持では $\delta=0.1 \sim 0.5 \mu \mathrm{m}$ で, 本 実験と同様に一度濡れた液滴が戻るため $\theta=50^{\circ} \sim 60^{\circ}$ の值を示 した。しかし $\delta \geqq 0.5 \mu \mathrm{m}$ では液滴が戻る現象は見られず， $\theta \leqq 5^{\circ}$ の值を維持した. したがって、イオンプレーティングし

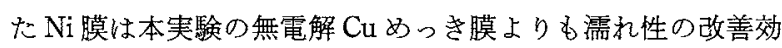
果が大きい、コーティングした金属膜が十分その効果を発掉て きないのは高温保持中儿金属膜が凝集して基艋表面が露出する ためである，そのような金属膜の凝集に影響を与兄る要因とし ては，前述のよらにコーティングした金属と基盤との接合の度 合，金属の自己桩散执よび表面張力等が考兄られるが，イオン プレーティング法で形成される皮膜は基盤との付着力が高く, しかも $\mathrm{Ni}$ の自己拡散係数は，例宇ば $973 \mathrm{~K}$ では $1.06 \times 10^{-19}$ $\mathrm{m}^{2} / \mathrm{s}$ と $\mathrm{Cu} 3.82 \times 10^{-16} \mathrm{~m}^{2} / \mathrm{s}$ より小さく $(17) ，$ かつ融点の高 い $\mathrm{Ni} \mathrm{Cu}$ より表面張力も小さいものと考克られ，金属膜に 欠陷が生じ難いすのと考觉られる。

\section{3. 無電解銅めっきした $\mathrm{Al}_{2} \mathrm{O}_{3}$ 緎維と溶融 $\mathrm{Al}$ の需れ性}

Fig. 8(a)，(b)に種々の膜厚で $\mathrm{Cu}$ めっさた $\mathrm{Al}_{2} \mathrm{O}_{3}$ 繊維プ リフォーム(繊維体積率=15\%) 亿対する溶融 $\mathrm{Al}$ の見かけの接 触角 $(\theta)$ と保持時間 $(t)$ の関俰を，保持温度 $973 \mathrm{~K}$ 拉よび 1073 $\mathrm{K}$ で測定した結果を示した。接触角の測定は，板状に配列さ せた長絨維の両端を黑鉛で固定するため，䋐維の長さ方向と直 角の方向から行った。

Fig. 8(a)の $973 \mathrm{~K}$ 保持の場合，無めっきの織維拉よび皮膜 の厚さ $(\delta)$ が約 $0.3 \mu \mathrm{m}$ 以下の瀻維束に対する $\theta$ の時間変化は 又られなかった。なお，無めっきの場合の $\theta$ が $144^{\circ} て ゙$ 基盤に 

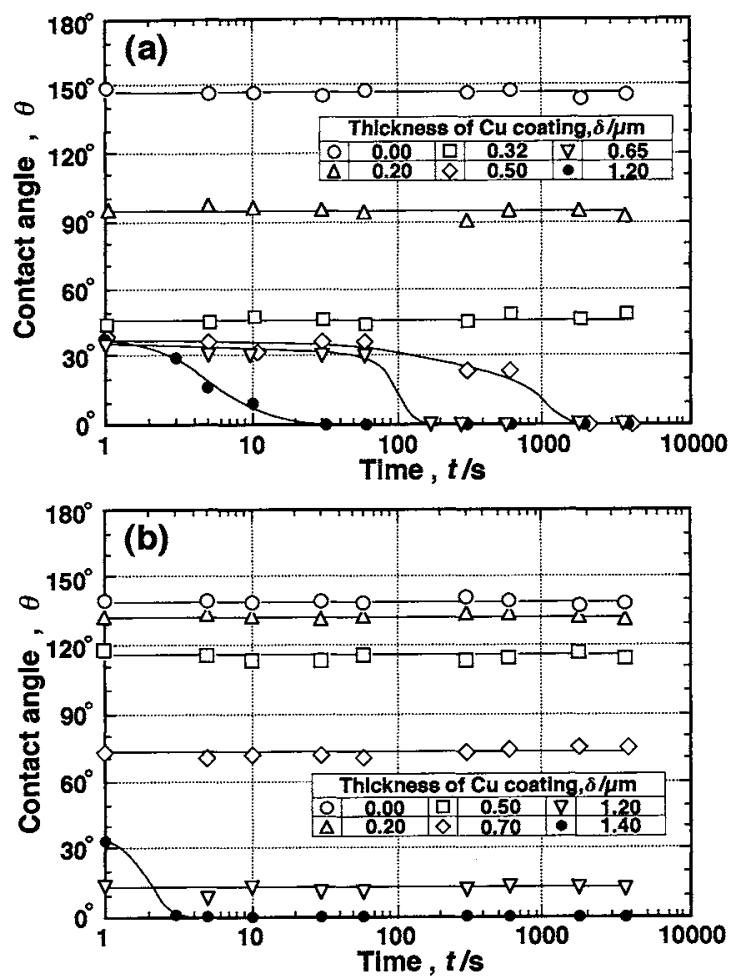

Fig. 8 Contact angle vs. time for molten $\mathrm{Al}$ on $\mathrm{Cu}$-plated $\mathrm{Al}_{2} \mathrm{O}_{3}$ fiber preform at (a) $973 \mathrm{~K}$, (b) $1073 \mathrm{~K}$ (volume fraction of fiber $=0.15$ ).

対する $\theta$ より高い値を示すのは，前述したよらに，液滴とプ リフォームの接触界面の面積が見かけの值より小さくなるため である. 整列した絒維とその間隙がプリフォームの表面を構成 している場合, Cassieのモデル(15)を用いて $\theta$ を推測すること ができる。このモデルは㵶維の配列方向からの見かけの $\theta$ を 求めるるのであるが，無めっきの試料の液滴は球に近い形状を しているため測定結果と比較できる.すなわら，

$$
\begin{aligned}
& \mathrm{f}_{1}=R \pi\left(1-\theta_{1} / 180\right) \\
& \mathrm{f}_{2}=1-R \sin \theta_{1}
\end{aligned}
$$

ここで, 表面構造因子 $R=r /(\boldsymbol{r}+d), r=$ 緎維半径, $2 d=$ 絨維の 間隔である.また，プリフォーム本体の気孔率 $V_{\mathrm{P}}\left(=1-V_{\mathrm{f}}\right)$ と $R$ 值との関俰は次式で表される(18).

$$
R=\sqrt{2 \sqrt{3}\left(1-V_{\mathrm{P}}\right) / \pi}
$$

式 $(1) \sim(4)$ K，繊維体積率 $V_{\mathrm{f}}=15 \%, \theta_{1}=113^{\circ}$ を代入する と $\theta=144^{\circ}$ となる.

一方， $\delta \geqq 0.5 \mu \mathrm{m}$ では $\theta$ は時間の経過とともに減少し， $3600 \mathrm{~s}$ 保持後は $0^{\circ}$ となった。この時, $\mathrm{Al}$ 液滴は絨維方向に平 行に広がりすざて繊維プリフォーム中に漫入した．Fig. 8(b)の $1073 \mathrm{~K}$ の場合す同様に $1.2 \mu \mathrm{m}$ 以下の $\delta$ K预いて $\theta$ の 時間変化はなかったが, $1.4 \mu \mathrm{m}$ では数秒で $\mathrm{Al}$ 液滴が瀻維中に 侵入したため見かけの日は $0^{\circ}$ をした。なお，Cuめっきした $\mathrm{Al}_{2} \mathrm{O}_{3}$ 基盤の場合と異なり, $1073 \mathrm{~K}$ 保持して専液滴が再び後 退する現象は見られなかった。

Fig. 9 は, 各試料の $\theta$ の代表值として, 時間変化率が小さ くなる $300 \mathrm{~s}$ 执よび $3600 \mathrm{~s}$ 後に括ける見かけの接触角 $(\theta)$ を採

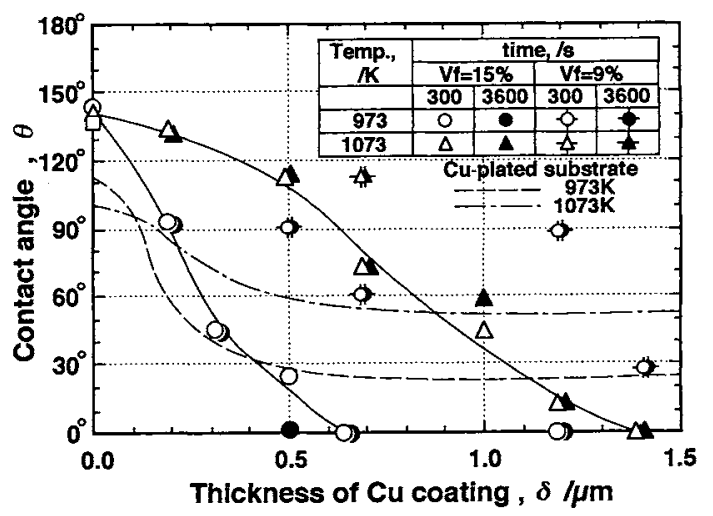

Fig. 9 Contact angle vs. thickness of $\mathrm{Cu}$ coating for molten $\mathrm{Al}$ on $\mathrm{Cu}$-plated $\mathrm{Al}_{2} \mathrm{O}_{3}$ fiber preform at 973 and $1073 \mathrm{~K}$ (wetting time: 300 and $3600 \mathrm{~s}$ ).

用し，皮膜の厚さ $(\delta)$ との関係を示したものである.な特, 図 中には前述した銅めっさ $\mathrm{Al}_{2} \mathrm{O}_{3}$ 基盤に対する $300 \mathrm{~s}$ 保持の $\theta$ を 破線括よび一点鎖線で示した。瀻維体積率が $15 \%$ の絨維プリ フォームでは，実線で示されるよらにいずれの温度でも $\delta 0$ 増加に伴い $\theta$ が減少する㑯向にある。特に，973 K 保持では $0.5 \mu \mathrm{m}$ 以上, $1073 \mathrm{~K}$ では $1.4 \mu \mathrm{m}$ 以上で濡れ性が著しく改善 され，溶融 $\mathrm{A} 1$ は繊維プリフォーム中へ溶浸した。 $1073 \mathrm{~K}$ 上 りも低温の $973 \mathrm{~K}$ 保持の場合が皮膜による濡れ性改善効果が 高いのは，前述のように液滴滴下時での皮膜の性状の差異にあ ると考充られる。すなわち皮膜が薄い場合なよび高温保持の場 合は，Cu吃基盤の場合と同様に表面の $\mathrm{Cu}$ 膜が昇温過程 扣よび高温保持中に凝集して $\mathrm{Al}_{2} \mathrm{O}_{3}$ が露出するためと考光ら れる。な扣，SEMによる観察から，皮膜は繊維に十分付着し て和り，絩維から䟝離することはなかった。

次火, $973 \mathrm{~K}$ 保持の場合，紻維体積率 $V_{\mathrm{f}} \not ゙ 9 \%$ と低い場合 には $\delta=1.2 \mu \mathrm{m}$ でも $\theta$ は約 $90^{\circ}$ と高い值を示し, 溶融 Al は緎 維束中へ侵入しなかった。これは上記の $V_{\mathrm{f}}=15 \%$ の場合とは 異なっている。そこで，この高い $\theta$ を示した試料の $\mathrm{Al}$ 液滴 と蟣維束の接触部近傍を SEM とより観察し，その結果を Fig. 10(a)，(b)に示した. Fig. 10(a)の中央部の溶融 $\mathrm{Al}$ は, 数十本の繊維から成る東ごとに吸引されている，しかし，束内 の䋐維間隔はかなり大きいため，溶融 $\mathrm{Al}$ は繊維間に浸透しき れず, $\mathrm{Al}$ 液滴自身の表面張力とバランスをとっている。李た， 溶融 $\mathrm{Al}$ の溶浸が起こった数十本の繊維をさらに詳しく観察 し, 液滴加 5 約 $2 \mathrm{~mm}$ の代表的广纎維表面組織火 Fig. 10 (b) に示した. 䋐維(b1)の表面は $[\alpha$ (死色部) $+\theta$ (白色部) $]$ 共晶組 織を示して括り， $\mathrm{Al}$ 液滴が $\mathrm{Cu}$ 皮膜を溶解した結果，形成さ れたと思われる。また(b2)の紷維は反応層の最先端になって いるが，Cu濃度が約75\%拉よび80\%と高い相があり， EPMA 分析結果怙よび Al-Cu 状態図から $\varepsilon$ 和よび $y$ 相と考兄 られる。こ礼らのことから, 溶融 $\mathrm{Al}$ は $\mathrm{Cu}$ 皮膜を溶解し $\mathrm{Al}$ $\mathrm{Cu}$ 合金を形成しながら進み，むる領域が共晶組成程度の $\mathrm{Cu}$ 濃度であれば，織維(b1)に示される組織となり，さらに溶融 $\mathrm{Al}$ が前進して Cu 皮膜を溶解すると, ついには瀻維 $(\mathrm{b} 2)$ の上 らに $y$ および $\varepsilon$ 相を晶出して溶融 $\mathrm{Al}$ は停止する。このような 緎維表面の組成変化は Fig. 5(a)〜 (c) と示した基盤の場合と類 


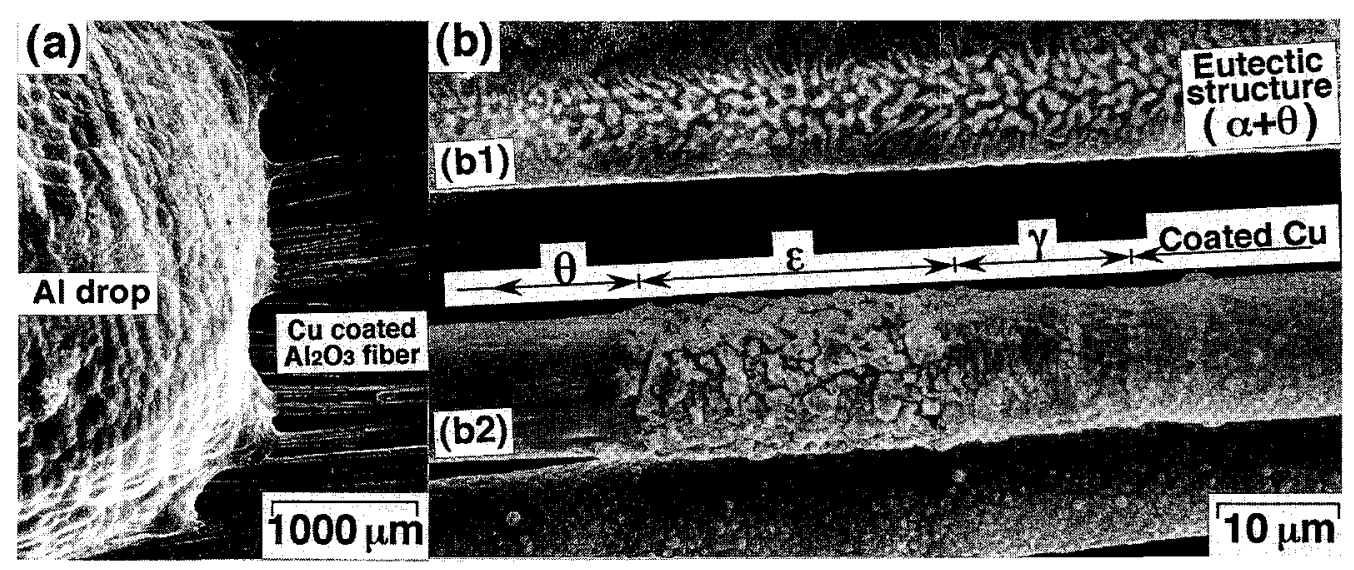

Fig. 10 Scanning electron micrographs of $0.9 \mu \mathrm{m}$ thick Cu-plated $\mathrm{Al}_{2} \mathrm{O}_{3}$ fibers held at $973 \mathrm{~K}$ for $3600 \mathrm{~s}$ (volume fraction of fiber $=0.09$ ), (a) near the periphery of $\mathrm{Al}$ drop, (b) reaction layer between molten $\mathrm{Al}$ and plated $\mathrm{Cu}$.

似している，以上のような反応層の生成は繊維分布状態に大さ く依存して赫り，密に分布しているところでは(b1)の瀻維の よらに，溶融 $\mathrm{Al}$ が他の繊維束にわたり，毛管現象により $\mathrm{Al}$ が溶浸する距離は長くなり，一方，(b2)の織維のように溶融 $\mathrm{A} 1$ が一本の繊維上を進む場合には，Cu濃度はすぐに高くなり 金属間化合物を晶出して溶浸は停止するのであるう。すなわら プリフォームの絨維体積率が比較的高く繊維の配列が均一でか る場合は溶融 $\mathrm{Al}$ は繊維間に十分浸透するが，不均一なプリフ ォームでは溶融 $\mathrm{A} 1$ は充填率の高い部分から溶浸し，充填率の 低い部分で停止するるのと考㝋られる。

\section{N. 結言}

夜相法に上る $\mathrm{Al}$ 合金と $\mathrm{Al}_{2} \mathrm{O}_{3}$ 系セラミックスとの複合化に おいて問題となる両者間の濡れ性の向上を目的として, $\mathrm{Al}_{2} \mathrm{O}_{3}$

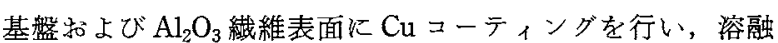
A1 との濡孔性に及ぼすコ一ティングの効果を調查し，以下の 結論を得た。

(1) $\mathrm{Al}_{2} \mathrm{O}_{3}$ 基盤に対する溶融 $\mathrm{Al}$ の接触角 $(\theta)$ は $973 \sim 1173$ Kで $113 \sim 92^{\circ}$ であり，温度の上昇に伴い低下した。をた $\mathrm{Al}$ 5.5 抢よび 33.0 mass\% $\%$ u 合金もほぼ同じ $\theta$ を示した。

（2）無電解銅めっきした $\mathrm{Al}_{2} \mathrm{O}_{3}$ 基盤に対する溶融 $\mathrm{Al} の \theta$ は, 皮膜の厚さ $(\delta)$ の増加とともに減少し, 特火 $973 \mathrm{~K}$ 保持で は $\delta か ゙ ~ 0.3 \mu \mathrm{m}$ 以上で $40^{\circ}$ 以下まで低下し濡れ性が著しく改善 された．高温保持中に皮膜が凝集して生じた欠陷，および $\mathrm{Cu}$ めっき層の制離などによって生じた皮膜 $/ \mathrm{Al}_{2} \mathrm{O}_{3}$ 間の隙間は， 濡れ性に及注す皮膜の効果を低下させる原因となるが，表面に 凹凸のある $\mathrm{Al}_{2} \mathrm{O}_{3}$ 基盤を使用 $\mathrm{L}, 973 \mathrm{~K}$ 保持で性 $\delta \geqq 0.5 \mu \mathrm{m}$, $1073 \mathrm{~K}$ 以上の温度では $\delta \geqq 0.9 \mu \mathrm{m}$ の皮膜を被覆することに上 り，この久宿の生成を抑えることができた。

（3）無電解銅めっきした $\mathrm{Al}_{2} \mathrm{O}_{3}$ 絨維束と溶融 $\mathrm{Al}$ との濡れ性 は，繊維体積率が高いプリフォームに拈いて低温保持であるほ ぞ，また皮膜の厚さが厚いほど向上し， $973 \mathrm{~K} て ゙ 0.5 \mu \mathrm{m}$,
$1073 \mathrm{~K} て ゙ 1.4 \mu \mathrm{m}$ 以上で溶融 $\mathrm{Al}$ はすべて自発的に絨維間に溶 浸した。

終わりに，反応層および液滴試料の定量分析は九州大学工学 部 IMA 実験室の EPMA 装置を利用したことを付記します． また，実験の遂行にあたってご協力いただいた福元広一氏 [現：本田技研工業侏]深く感謝します。

\section{文献}

(1) F. A. Badia, D. F. MacDonald and J. R. Pearson: AFS Transactions, 79(1971), 265.

(2) A. M. Patton: J. Inst. Metals, 100(1972), 197.

（3）福永秀春, 合田公一：日本複合材料学会誌, 12(1986), 198.

(4) J. J. Brennan and J. A. Pask: J. Amer. Ceram. Soc., $\mathbf{5 1}(1968), 569$.

( 5 ) K. Prabriputaloong and M. R. Piggott: Surface Scince, 44 (1974), 585.

(6) W. Dawihl and H. Federmann: Aluminium, 50(1974), 574.

（7）森信幸，宮原広郁，古閑正明，大城桂作：日本金属学 会誌, 55(1991), 444 .

（8）逢坂哲㢼，中村英治，田宫幸広，小岩一郎：表面技術， $40(1989), 573$.

（9）本間英夫，小松㩐正：サーキットテクノロジ，3(1988), 204.

（10）本間英夫, 河内康徳, 安田伸一朗：サーキットテクノ口 ジ, 4(1989), 41.

(11) G. V. Elmore and R. F. Hershberger: J. Electrochem. Soc., 121(1974), 107.

（12）森 信幸, 松尾 識, 大城桂作, 松田公扶：日本金属学 会誌, 51(1987), 240.

(13) R. N. Wenzel: Ind. Eng. Chem., 28(1936), 988.

(14) S. J. Hitchcock, N. T. Carroll and M. G. Nicholas: J. Mater. Sci., 16(1981), 714.

(15) A. B. D Cassie and S. Baxter: Trans. Faraday Soc., $40(1944), 546$.

(16) M. Hansen: McGraw-Hill Book Co., Inc., (1958), 85.

(17) H. Mehrer: Diffusion in Solid Metals and Alloys, SpringVerlag, (1990), 52.

（18）森 信幸, 浮田 求, 大城桂作：日本金属学会誌, $\mathbf{5 5}(1991), 820$. 